PETER K. CLARK

Stanford University

\title{
Issues in the Analysis of Capital Formation and Productivity Growth
}

For NEARLY TWO DECADEs between World War II and the mid-1960s, real output per hour of labor input in the private sector of the U.S. economy grew at an average rate of nearly 3 percent a year. Since then, this measure of labor productivity has decelerated noticeably, first to about 2 percent a year between 1965 and 1973, and then to 1 percent or less a year between 1973 and 1978. This slowdown is an important macroeconomic phenomenon that has sparked interest in the academic community, the government, and the business press.

Although there can be no doubt that growth of labor productivity, however defined, has slowed dramatically in the past ten or fifteen years, the particular data used to measure the growth of input and output have a substantial effect on the estimated magnitude of the slowdown, and an even more important influence on estimates of what caused it. In this paper I present different measures of real output, labor input, and capital input for the private nonfarm nonresidential business sector of the U.S. economy, and compare the results obtained by choosing various sets of series to analyze recent productivity trends.

\section{Measures of Real Output}

Disagreement about the appropriate measure of output has been an issue in the analysis of productivity trends ever since the sharp exchange

Note: This research was supported in part by a national fellowship from the Hoover Institution on War, Revolution, and Peace at Stanford University. 
of views between Edward F. Denison and Dale W. Jorgenson and Zvi Griliches. ${ }^{1}$ Jorgenson and Griliches maintain that output should be measured by gross product; Denison advocates net product, with a subtraction for depreciation of the capital stock. Jorgenson and Griliches prefer to aggregate all goods and services delivered to final demand, while Denison points out that this gross aggregate is unavailable for sustained consumption because part of the capital stock is used up in its production.

An additional question raised in this debate is which set of prices to use in the aggregation of output. At various times, Jorgenson and Griliches have used market prices (with excise taxes on output included) and producer prices (with excise taxes on output excluded). ${ }^{2}$ Denison evaluates output at factor cost, subtracting indirect business taxes on both output and input from gross product. ${ }^{3}$ Here again, the choice is equivocal - producer prices evaluate inputs from the point of view of the users of inputs; factor cost, from the point of view of their suppliers.

The first four rows in table 1 compare rates of growth of output for the nonfarm nonresidential business sector, calculated in different ways, with a view toward isolating the effects of different measurement methods. The subtraction of straight-line depreciation (second row) or "one-hoss shay" retirements (fourth row) makes only a small difference in the calculated growth rate of output; the largest difference is the 0.24 percentage point a year between the GNP and NNP concepts during the 196573 period. Differences in the other two time-periods are considerably smaller. Growth rates calculated using net output measures indicate a slight slowdown in the 1965-73 period; as a consequence, the labor productivity slowdown in 1973-78 relative to $1965-73$ is generally smaller with net output than with gross output. Differences between growth rates of output aggregated using market prices and factor cost are minuscule.

1. For a compilation of the various articles written on both sides of this debate, see "The Measurement of Productivity," Survey of Current Business, vol. 52 (May 1972, pt. 2), pp. 3-111.

2. For market prices, see D. W. Jorgenson and Z. Griliches, "The Explanation of Productivity Change," Review of Economic Studies, vol. 34 (July 1967), pp. 249-83. For producer prices, see Dale W. Jorgenson and Zvi Griliches, "Issues in Growth Accounting: A Reply to Edward F. Denison," Survey of Current Business, vol. 52 (May 1972), pt. 2, pp. 65-94.

3. Edward F. Denison, Accounting for United States Economic Growth, 19291969 (Brookings Institution, 1974). 
Table 1. Rates of Growth of Output and Input, Nonfarm Nonresidential Business Sector, Selected Periods, 1948-78

Annual average, in percent

\begin{tabular}{llll}
\hline Measure & $1948-65$ & $1965-73$ & $1973-78$ \\
\hline
\end{tabular}

Output

Gross output evaluated at 1972 market prices

(GNP concept)

Net output evaluated at 1972 market prices

(NNP concept)

Net output evaluated at 1972 factor cost (NI concept)

Net output evaluated at 1972 market prices (consistent with "one-hoss shay" depreciation) ${ }^{\mathrm{a}}$

$3.75 \quad 3.60 \quad 2.31$

Labor input

Hours worked

Full-time equivalent employment

Full-time and part-time employment

\section{Capital input}

Gross capital stock ("one-hoss shay"

$$
\text { depreciation) }{ }^{\mathbf{a}}
$$

4.52

Net capital stock (straight-line depreciation)

4.81

Gross capital services (adjusted for shift from structures to equipment)

3.53

4.60

Sources: The measures of output are from the U.S. Bureau of Economic Analysis, national income and product accounts. Labor inputs (hours, full-time and part-time employment, and full-time equivalent employment) are calculated from Bureau of Economic Analysis and U.S. Bureau of Labor Statistics data in a manner similar to that used in Edward F. Denison, Accounting for United States Economic Growth, 1929-1969 (Brookings Institution, 1974). Hours worked data are from the Bureau of Labor Statisics. The series for net and gross capital stock are from the Bureau of Economic Analysis and are described in John C. Musgrave, "Fixed Nonresidential Business and Residential Capital in the United States, 192975," Survey of Current Business, vol. 56 (April 1976), pp. 46-52. For the procedure used to adjust the capital services series, see the discussion in the text. Figures are rounded.

a. This assumes that an investment is carried at its full value in the capital stock until the end of its useful lifetime.

\section{Measures of Labor Input}

The calculation of labor input is complicated by a serious aggregation problem; labor "quality" varies from worker to worker. To account for changes in the average "quality" of an hour worked, analysts of growth typically calculate adjustments for the age, sex, and education of the labor 
force. ${ }^{4}$ There is general agreement that adjustments for age and sex can explain a small part (a quarter or less) of the decline in growth of output per hour of labor input between 1965 and 1973. In the 1973-78 period, the shift toward lower-paid age and sex categories slowed a little, implying that shifts in the age-sex composition of the work force since 1973 have been a slight help in preventing an even larger reduction in productivity growth.

A different issue concerning labor input is important in determining the effect of capital intensity on the growth of labor productivity. Although "hours" or "quality-adjusted hours" is the standard measure of labor input, a case can be made for adjusting hours to a full-time equivalent basis to account for reduction in the workweek of capital. For example, suppose that in 1965 an office building and its associated equipment (worth $\$ 1$ million at 1972 prices) combined with twenty workers on the job forty hours a week to produce output worth $\$ 600,000$ (at 1972 prices). The capital-labor ratio, as conventionally defined, would be $\$ 1,250$ per labor-hour each week. Later, in 1973, assume that the office building still holds twenty full-time workers, but that they work only thirty-five hours each week. If the value of the building and equipment is unchanged, and output falls to $\$ 525,000$ (1972 prices), conventional measures would indicate that labor productivity remained constant while the capital-labor ratio rose 14 percent. However, at any time the office was open in 1973, an observer would find that the ratio of capital to workers was exactly the same as it was in 1965 . Output per full-time worker and capital stock per full-time worker remain unchanged.

The reverse situation would occur if there were a systematic move toward more intensive utilization of capital. For example, the trend toward longer business hours for retail establishments could have lowered the ratio of capital to hours worked without decreasing actual capital intensity of production. The problem in both cases is that measured changes in the capital-labor ratio may have been generated either by shifts in the amount of capital available to each worker while he is on the job, or by changes in the average workday of capital. Although increases in capital available

4. For example, see Edward F. Denison, "Explanations of Declining Productivity Growth," Survey of Current Business, vol. 59 (August 1979), pt. 2, pp. 1-24; Peter K. Clark, "Capital Formation and the Recent Productivity Slowdown," Journal of Finance, vol. 33 (June 1978), pp. 965-75; the article by J. R. Norsworthy, Michael J. Harper, and Kent Kunze in this issue; and earlier work by Denison, Jorgenson, and Griliches. 
Table 2. Rates of Growth of Alternative Measures of the Capital-Labor Ratio, Nonfarm Nonresidential Business Sector, Selected Periods, 1948-78

Annual average, in percent

\begin{tabular}{lccc}
\hline \multicolumn{1}{c}{ Ratio } & $1948-65$ & $1965-73$ & $1973-78$ \\
\hline Net capital stock to hours worked & 2.93 & 3.07 & 1.32 \\
$\begin{array}{l}\text { Net capital stock to full-time equivalent } \\
\text { employment }\end{array}$ & 2.99 & 2.20 & 1.07 \\
$\begin{array}{l}\text { Gross capital services to hours worked } \\
\begin{array}{l}\text { Gross capital services to full-time } \\
\quad \text { equivalent employment }\end{array}\end{array}$ & 2.55 & 2.86 & 1.81 \\
\hline
\end{tabular}

Sources: Same as table 1. Figures are rounded.

to each worker while he is on the job should increase labor productivity, the effect of decreases in the workweek of capital is less clear.

The distinction between hours and employees is particularly important in the 1965-73 period, as shown in table 1 . Before 1965, most of the difference between growth in hours and growth in employment can be attributed to increases in the proportion of part-time workers. But during the 1965-73 period, reductions in the full-time workweek more than accounted for the substantial difference between the rates of growth of hours and employment. This sharp 1965-73 reduction in the average workweek raises the possibility that the capital intensity of production continued to fall between 1965 and 1973, as shown in table 2.

When the capital-labor ratio is the net stock of capital divided by hours worked, its rate of growth increases from 2.93 percent a year in 1948-65 to 3.07 percent a year in 1965-73, and then falls off precipitously to 1.32 percent a year in 1973-78 just as Norsworthy, Harper, and Kunze point out. However, if the sharp drop in the 1965-73 period in the number of hours for full-time workers generated a spurious increase in the capitallabor ratio, and the ratio of capital stock to full-time equivalent employment is a better measure of capital intensity, then a less confusing pattern emerges. Net capital stock per full-time equivalent employee grows at 2.99 percent a year in the 1948-65 period, 2.20 percent in 1965-73, and 1.07 percent in 1973-78. In terms of gross capital services and full-time equivalent employment, the deceleration in the growth of capital intensity is smaller, but still divided evenly between 1965-73 and 1973-78. This pattern of slowing growth of capital intensity in both periods is more consistent with the observed behavior of labor productivity. 


\section{Measures of Capital Input}

When the analysis of productivity is expanded to include the services of capital as an input, it is typically assumed that capital input is proportional to some aggregate measure of the capital stock. The U.S. Bureau of Economic Analysis publishes two such measures: a gross stock, in which an investment is carried at its full value in the capital stock until the end of its useful lifetime ("one-hoss shay" depreciation), and a net stock, in which an investment is reduced by a constant amount in the capital stock each year (straight-line depreciation). For the purposes of analyzing productivity growth, a series that approximates the "physical" amount of capital services used in the production process is of interest, so the choice of a depreciation schedule is essentially an empirical question. If capital retains its efficiency over its estimated lifetime, the gross stock is appropriate. If capital loses efficiency linearly, so that it is only half as efficient at the midpoint of its life, then the net measure is correct. Casual empiricism seems to indicate that "one-hoss shay" depreciation is closer to the truth, and therefore the gross measure is more appropriate for productivity analysis.

Such a simple notion of a physical amount of capital input ignores a number of problems, including two that are discussed below: the durability of capital goods and the embodiment of technical progress in newer capital equipment. The aggregation of the capital stock is in terms of value; the dollar cost of an asset is deflated to a common base (1972 prices) and then added to the capital stock. If it is possible to buy more durable capital equipment at a higher cost, changes in the average durability can cause a constant value aggregate to misstate the growth of the physical amount of capital input.

For example, consider a world in which there are only two kinds of capital goods: wooden hoes and aluminum hoes. These hoes are totally interchangeable in production, but the wooden hoes last for only one year, and the aluminum ones last for five years and cost three times as much. As long as the average ratio of wooden hoes to aluminum hoes in the economy remains constant, a value aggregate for the capital stock will track the growth of physical capital input (number of hoes) correctly. But if, for some reason, the ratio of wooden to aluminum hoes increases, a value aggregate understates the growth in physical capital input. 
The shift in the composition of the U.S. capital stock from structures to equipment over the past thirty years entails just this sort of reduction in durability. A rough adjustment for the rise in capital services attributable to this shift may be calculated by first assuming that equipment and structures have physical lifetimes of fifteen and forty years, respectively. If it is assumed that the ratio of capital services to capital stock remains constant for equipment, structures, and inventories, the growth rates of each component may be aggregated with constant weights to obtain the growth rate of gross capital services shown in the last row of table $1 . .^{5}$ The shift from structures to equipment has apparently been smooth enough so that the rates of growth of capital input with this adjustment are similar to the other measures in the table. The growth rate of the gross capital stock increased 1.12 percentage points a year faster in the 1965-73 period than it did in the 1948-65 period; the speedup for gross capital services is 1.07 percentage points. The two estimates for the slowdown in capital input growth after 1973 are also close: 1.28 percentage points for the gross capital stock and 1.23 points for gross capital services. The shift from structures to equipment has not been an additional factor in the slowdown of labor productivity in either $1965-73$ or 1973-78.

Another complication enters when one allows for the possibility that a substantial fraction of technical progress is embodied in new capital. For example, suppose that 1 percentage point (or nearly all) the growth in total-factor productivity over the past thirty years is attributable to improvements in capital efficiency. This would mean that each year the same number of (deflated) dollars' worth of new capital stock, when combined with a given amount of labor, would produce 1 percent more output than a process using capital that is one year old. If this were the case, changes in the average age of the capital stock would have an effect on the growth of labor productivity. Because the "newness" of capital may be inferred from the ratio of net to gross capital stocks, the effect of 1 percent (a year) embodiment may be calculated. Such an estimate is incorporated in table 3. Even this extreme assumption can explain only a reduction of 0.1 percentage point in growth of labor productivity in the 1965-73 period, and an additional decline of 0.1 percentage point in the 1973-78 period.

5. This amounts to a simplified version of the Divisia aggregation discussed by Norsworthy, Harper, and Kunze in this issue. The weights used were 0.167 for equipment, 0.125 for structures, and 0.100 for inventories, corresponding to a real discount rate of 10 percent a year. 
Table 3. Rates of Growth of Labor Productivity and of Contribution from Capital Formation, Nonfarm Nonresidential Business Sector, Selected Periods, 1948-78

Annual average, in percent

\begin{tabular}{lccc}
\hline \multicolumn{1}{c}{ Item } & $1948-65$ & $1965-73$ & $1973-78$ \\
\hline $\begin{array}{l}\text { Gross output per hour worked } \\
\text { Contribution to growth }\end{array}$ & 2.75 & 2.09 & 0.92 \\
$\begin{array}{l}\text { Using net capital } \\
\quad \text { Net capital stock per hour worked }\end{array}$ & 0.94 & 1.02 & 0.44 \\
$\quad \begin{array}{l}\text { Other factors } \\
\text { Using gross capital and vintage effects } \\
\quad \text { Gross capital services per full-time } \\
\quad \text { equivalent employee }\end{array}$ & 1.81 & 1.07 & 0.48 \\
$\quad \begin{array}{l}\text { Capital vintage effect at a 1 percent } \\
\quad \text { embodiment rates }\end{array}$ & 0.87 & 0.67 & 0.52 \\
$\quad$ Other factors & 0.14 & 0.05 & -0.05 \\
\hline
\end{tabular}

Source: Computed from the data in table 1, assuming a Cobb-Douglas production function with a coefficient of one-third on the capital input. Figures are rounded.

a. For the procedure used to calculate this effect, see the discussion in the text.

\section{The Productivity Mystery}

Many of the measurement issues examined above do not have much empirical relevance. Output grows at about the same rate whether it is measured in gross or net terms; potential aggregation problems associated with the shift from structures to equipment in the capital stock seem to be minor; and shifts in the average "newness" of capital could have contributed only a small amount to the observed slowdown in the growth of labor productivity. In two respects, however, data considerations do seem to make a difference. First, traditional estimates of the capital intensity of production (capital per hour worked) may be confounded by the substantial decline in full-time weekly hours between 1965 and 1973. It is possible that the capital intensity of production fell slightly in response to the tremendous acceleration of employment during that period, rather than rising, as the standard estimate indicates. Second, it is likely that net measures of the capital stock overstate physical depreciation since 1973, and therefore also overstate the deceleration in capital input since that date.

The effect of these considerations can be seen in table 3. The second and third rows ("using net capital") show a Norsworthy type of calculation that uses net capital stock per hour worked as the measure of capital 
intensity of production. The capital-labor ratio is estimated to have increased the growth of labor productivity in the 1965-73 period, and then to have reduced it by 0.6 percentage point a year in the 1973-78 period. The unexplained part of productivity growth ("other factors") still falls almost as much in the 1973-78 period as it did in the 1965-73 period, partly because adjustments for pollution abatement capital and quality of the labor force were not included, and also because elimination of residential output makes the decline of productivity in the 1973-78 period larger than it is in estimates by Norsworthy, Harper, and Kunze. In the last three rows of table 3 ("using gross capital and vintage effects") some of the slowdown in labor productivity in each of the two later periods is attributed to successive reductions in the growth of capital intensity. In this case, the unexplained reduction in the growth of labor productivity is larger in the 1973-78 period than in the 1965-73 period. Either type of calculation shown in the table indicates that "the case of the missing productivity" is a two-part mystery extending through both the 1965-73 and 1973-78 periods. 